\title{
Ameliyat Geçiren Hastalarda Konfor Düzeyi ve Etkileyen Faktörlerin İncelenmesi
}

\author{
Perianesthesia Comfort Levels of the Patients Undergone Operation and It's Affecting Factors
}

\author{
Pınar BÜYÜKÜNAL ŞAHİN ${ }^{a}$ Selda RIZALAR ${ }^{b}$
}

ÖZ Amaç: Bu çalışma, cerrahi girişim uygulanan hastalarda konfor düzeyini ve etkileyen faktörleri incelemek amacı ile tanımlayıcı olarak yapıldı. Gereç ve Yöntemler: Araştırma evrenini 1 Şubat 2016 - 30 Eylül 2016 tarihleri arasında ameliyat geçiren bireyler, örneklemi ise araştırma kriterini karşılayan ve araştırmanın amacı açıklanarak bilgilendikten sonra izin alınan 218 birey oluşturdu. Verilerin toplanmasında Hasta Tanıtım Formu ve Perianestezi Konfor Ölçeği (PKÖ) kullanıldı. Verilerin değerlendirilmesinde SPSS 23.0 paket programı ile tanımlayıcı istatistiksel yöntemlerin yanı sıra Kolmogorov-Smirnov, Mann Whitney U ve Kruskal Wallis testleri kullanıldı. İstatistiksel olarak $\mathrm{p}<0.05$ anlamlı kabul edildi. Bulgular: Cerrahi girişim uygulanan bireylerin konfor ölçeği puan ortalaması 4,82 $\pm 0,61$ bulundu. Cerrahi girişim uygulanan bireylerin tanıtıcı özellikleri ile konfor puanları karşılaştırıldığında erkek hastaların konfor düzeyinin kadınlardan yüksek olduğu ve daha önce ameliyat geçirmenin konfor düzeyini arttırdığı belirlendi. Ameliyat geçiren bireylerin hastalık ve ameliyata ilişkin özelliklerine göre konfor puanları değerlendirildiğinde, ameliyat tipine göre konfor puanları arasında anlamlı fark bulundu. Sonuç: Genel cerrahi ameliyatları içinde yer alan kolesistektomi ameliyatı geçiren hastaların konfor düzeyinin diğer ameliyatları geçiren hastalardan yüksek olduğu, hastaların ağrı düzeylerine göre karşılaştırma yapıldığında şiddetli ağrısı olan hastaların konfor düzeyinin düşük olduğu belirlendi.

Anahtar Kelimeler: Ameliyat, ameliyat sonrası bakım, hemşirelik, konfor, perianestezik bakım

\begin{abstract}
Objective: The purpose of this descriptive study was to determine the perianesthesia comfort levels of the patients undergone an operation and affecting the factors. Methods: Research population included persons undergone operation between $1^{\text {st }}$ February - $30^{\text {th }}$ September 2016, while research sample included 218 patients meeting research criteria and informed on research aim and consented therefor. Data were collected with Patient Identification Form and Paranesthesia Comfort Questionnaire (PCQ). To evaluate the data, SPSS 23.0 packaged software and descriptive statistical methods as well as Kolmogorov-Smirnov, Mann Whitney U and Kruskal Wallis tests are used. Statistical value of $p<0.05$ was accepted as significant. Results: Comfort scale point average of the patients undergone operation was seen as $4,82 \pm 0,61$. Among the groups in which the descriptive features of the patients undergone operation were compared, it was stated that comfort level of male patients were high and undergoing an operation previously increased comfort level. Among the groups compared according to disease and operation of the patients undergone operation, comfort score with respect to the operation type -while analyzingwere found significant difference. Conclusion: It was also stated that comfort level of patients undergone cholecystectomy operation which one of the general surgery operations are high and the patients having severe pain levels have low comfort level while the patients were compared as to their pain levels.
\end{abstract}

Key Words: Surgical operation, nursing, comfort, perianesthesia care, postoperative care

\section{Giriş}

Konfor, temel insan gereksinimlerinden biridir ve özellikle sağlık bakımına gereksinim duyulduğu zaman dikkate alınması istenir. Hastanede yatan hastalarda konforun hem fiziksel hem de duygusal yönden hastane deneyimleri üzerinde etkili olduğu belirlenmiştir $(1,2)$. Konfor ya da rahatlık insan- oğlunun doğumundan itibaren aranılan bir durum ve ulaşllmak istenen bir hedeftir. Bir bebeğin kucağa alındığı zaman sakinleşmesi, yaralanan bir çocuğun okşandığında ağlamasının durması, yaşlı bir kimsenin yanında oturup dokunsal temas

Geliş Tarihi/Received:14-02-2018-Kabul Tarihi/Accepted:28-04-2018

aUzm Hem, Pendik Medikal Park Hastanesi, e-mail:pinarbuyukunal@gmail.com,

bİstanbul Medipol Üniversitesi, Sağlık Bilimleri Yüksekokulu, Hemşirelik Bölümü, e-mail:srizalar@medipol.edu.tr

Sorumlu Yazar /Correspondence: Yrd Doç Dr Selda Rızalar, İstanbul Medipol Üniversitesi Sağlık Bilimleri Yüksekokulu Hemşirelik Bölümü Unkapanı/ISTANBUL, e-mail:srizalar@medipol.edu.tr

*Çalışma 2-5 Kasım 2017 tarihleri arasında gerçekleştirilen 2. Uluslararası 1. Ulusal Türk Ameliyathane ve Cerrahi Hemşireliği

Kongresi'nde sunulmuştur. 
uygulanması sonucu rahatlaması konforu gösteren durumlardır $(3,4)$.

Yaşam boyunca anlamlı bir gereksinim olarak var olan konfor hemşirelikte yeni bir kavram değildir. Birçok hemşire kuramcı tarafından rahatlık gereksinimi ve rahatlatmanın önemi dile getirilmiştir. Florence Nightingale'den bu yana geçerli, önemli ve güncel bir kavram olarak var olan konfor, bütüncül hemşirelik bakımının tartışmasız temel bir ögesi olarak ele alınmıştır. Günümüzde de konfor kavramı hemşirelik bakım kalitesinin bir parçasıdır; rahat, sıkıntısız hastaların daha çabuk iyileştiği, hastalık stresi ile daha iyi baş ettiği, daha iyi rehabilite olduğu ve daha huzurlu öldüğü belirtilmiştir $(3,4)$. Olumsuz koşulların birçoğu rahatsızlık olarak adlandırılır ve genellikle rahatsızlığın nedeni ve sonucu bir arada bulunur. Konfor, rahatlığın tersi olan rahatsızlık nedenlerinin ortadan kaldırılması ya da etkilerinin azaltılması ile elde edilir. Hemşireler, rahatsızlığın kaynağını genellikle hasta etkilenmeden önce tanımlar ve bu kaynağı uzaklaştırmaya yönelik girişimlerde bulunurlar. Proaktif bir yaklaşımla rahatsızlık durumu ortaya çıkmadan konfor oluşturulabilir (4).

Kolcaba'nın belirttiğgine göre, 1926'da Harmer hemşirenin çevresel rahatlığ 1 sağlamasının önemini tartışmıştır. Ağrının giderilmesinin ve ağrının verdiği rahatsızlıkların azaltılmasının iyi uygulamaların en önemli noktası olduğunu gözlemlemiştir. Goodnow 1935'de The Technic of Nursing kitabında hastaların rahatlığını sağlamanın ve sürdürmenin önemine değinmiştir. Goodnow'a göre hemşire hastanın rahatlı̆̆ını sorgulamalıdır, rahatlik hem fiziksel hem de zihinsel anlamda ele alınmalıdır ve hemşirenin sorumluluğu sadece fiziksel bakım sağlamakla sınırlı değildir (3).

Williams ve İrurita hemşireliğin rahatllk kavramı üzerine temellendiğini ve rahatlığın bireyi güçlendirme süreci olduğunu belirtmiştir. Konforu yetersiz olan hastaların güçsüz bireyler olduğunu iyileşme için güçlendirmeye ihtiyaç duyduğunu savunmuştur (1). "Kolcoba ve Wycle" rahatlı̆̆ sağlanan hastaların daha hılı iyileştiğini ve daha iyi baş ettiğini bulmuşlardır (5). Yapılan çalışmalarda konfor gereksinimlerine odaklanan hemşirelik girişimlerinin bakım kalitesi ve hasta memnuniyeti ile ilişkili olduğu görülmüştür $(6,7)$. Perioperatif süreçte konfor konusunda bir teorik çerçeve oluşturulması, hastanın konforunu sağlayacak kişiler olan hemşirelerin bilgilenmesi ve donanım kazanmasını sağlayacaktır. Teoriye göre, hastaların eski sağlığına kavuşmasında ve tedavi sonrası izlemde konfor sağlamanın amacı ameliyat öncesi işlevleri yeniden kazanması ve geleceğe güven duyması konusunda hasta bireyi güçlendirmektir $(7,8)$.

Cerrahi girişim uygulanan hastalarda konforun sağlanması ve sürdürülmesi bakım amaçları arasında yer almalıdır. Bakım bütüncül yaklaşımla, konforun dört boyutunu içerecek şekilde planlanmalıdır. Ancak bu şekilde hasta kendini ferah, konforlu ve sorunların üstesinden gelebilecek güçte hissedebilir. Hemşireler hasta bakımında konfor düzeyini belirleyerek verdikleri hizmetin kalitesini ölçebilir ve hasta bakımında beklenen sonuçları değerlendirebilir, aynı zamanda bakım konusunda yazılı kayıt oluşturabilirler $(6,7)$. Cerrahi girişimler, yaşamı güvence altına alan uygulamalar olmakla beraber hasta için psikolojik, fizyolojik ve sosyal yönden travmadır. Hasta cerrahi girişim sürecinde birçok fiziksel ve psikososyal sorunla karşı karşıya kalmaktadır $(9,10)$. Bütün bu sorunlar hastanın konforunun bozulmasına neden olmaktadır $(11,12)$. Bu araştırma, cerrahi girişim uygulanan hastalarda konfor düzeyi ve etkileyen faktörlerin incelenmesi yolu ile hasta bakım kalitesini yükseltmek ve hemşirelik girişimlerine rehberlik etmek amaciyla planlanmıştır.

\section{Gereç ve Yöntem}

\section{Araştırmanın Türü, Yeri-Zamanı ve Evren- Örneklemi}

$\mathrm{Bu}$ araştırma cerrahi girişim uygulanan hastalarda konfor düzeyi ve etkileyen faktörlerin incelenmesi amacıyla yapılan tanımlayıcı tipte bir çalışmadır. Araştırmanın evrenini özel bir hastanenin cerrahi kliniklerinde yatan ameliyat geçirmiş hastalar oluşturmaktadır. Araştırmanın yürütüldügü hastanede son 6 ay içinde yapılan ve en az 24 saat takip edilen 768 ameliyat olduğu belirlendi. Yapılan güç analizi sonucunda 0.05 güven düzeyinde $\% 90$ güçlülükte değer elde edebilmek için örneklemin en az 139 kişi olması gerektiği bulundu. Veri kaybı olabileceği düşünülerek 218 hasta ile görüşme yapıldı. Örneklemi 218 hasta oluşturdu. Araştırma örneklemine 18 yaş ve üzerinde olan, genel ya da spinal anestezi altında cerrahi girişim yapılan, kişi yer ve zamana oryante olan, ameliyat sirasinda temel yaşam işlevleri ile ilgili komplikasyon 
gelişmeyen hastalar dahil edildi. Mekanik ventilasyon desteği, işitme kaybı ve psikiyatrik hastalık tanısına sahip olan bireyler araştırma kapsamına alınmadı.

\section{Veri Toplama Araçları}

Araştırmanın verileri Hasta Tanıtım Formu ve Perianestezi Konfor Ölçeği ile toplandı.

Hasta Tanitım Formu: Hasta tanitım formu hastaların bireysel tanıtıcı özellikleri ile hastalığa ve ameliyata ilişkin özelliklerinden oluşmuştur. Bireysel tanıtıcı özellikleri; cinsiyeti, yaşı, medeni durum, eğitim durumu, gelir düzeyi, sosyal güvencesi, kronik hastalık, ilaç kullanımı ve alışkanlıkları içermektedir. Hastalığa ve ameliyata ilişkin özellikleri ise; şimdiki ameliyata karşı tutumu, refakatçi durumu, ameliyat planı, ameliyat şekli, anestezi türü, geçirilmiş ameliyat ve önceki hastane izlenimleri oluşturmaktadır. Ameliyat sonrası ağrının yeri ve şiddeti, analjezik ve antiemetik kullanımı ve önceden ameliyat geçirme durumlarını içermektedir.

Perianestezi Konfor Ölçeği: PKÖ, Kolcaba tarafindan konforun kuramsal bileşenlerini oluşturan üç düzey ve dört boyutun yer aldığ 1 taksonomi yapı rehber alınarak oluşturulmuştur. Ölçek bireyin cerrahi girişim öncesi ve sonrası hakkında genel düşünce sürecini yansıtan kendini kavrama ve hislerini sorgulayan 24 maddeden oluşmuştur. Ölçekteki her bir ifade "kesinlikle katılmıyorum"dan "kesinlikle katıllyorum" a doğru 1-6 arasında değişen likert tipi puanlamaya sahiptir. Olumlu ve olumsuz maddelerden oluşan ölçeğin yanıt düzenleri karışık halde verilmiştir. İfadelerin 12 'si olumlu $(1,5,6,11,14,16,18,19$, $20,21,23,24), 12$ 'si olumsuz $(2,3,4,7,8,9,10$, $12,13,15,17,22)$ olup; puanlamada olumsuz ifadeler tersine çevrilir. Buna göre olumlu ifadelerde yüksek puan (6) yüksek konfora, düşük puan (1) düşük konfora, olumsuz maddelerde ise düşük puan (1) yüksek konfora, yüksek puan (6) ise düşük konfora işaret etmektedir. Ölçeğin değerlendirmesinde; elde edilen olumsuz puanlar ters kodlanarak olumlu maddelerle toplanır. Ölçekten alınabilecek en yüksek toplam puan 144, en düşük toplam puan ise 24 dür. Elde edilen toplam puan ölçek maddelerinin sayısına bölünerek ortalama değer saptanır ve sonuç 1-6 dağılımında belirtilir. Düşük puan konforun kötü, yüksek puan konforun iyi olduğunu göstermektedir. Ölçeğin Türkçe geçerlik ve güvenirliliği Üstündağ ve Aslan tarafından yapılmıştır. Üstündağ ve Aslan'ın çalışmasında Cronbach alfa değeri 0,83 bulunmuştur(13). Çalışmamızda ölçeğin Cronbach alfa değeri 0,747 bulundu.

Veriler ameliyat sonrası dönemde araştırmacı tarafından çalışma konusunda katılımcılar bilgilendirilerek hasta odasında karşılıklı görüşme tekniği ile toplandı. Anket formunun yanıtlanması 15-20 dakika sürdü.

\section{Verilerin Değerlendirilmesi}

Veriler istatistik SPSS 23 (Statistical Package for Social Sciences) programı kullanılarak bilgisayar ortaminda analiz edildi. Verilerin analizi \%95 güven düzeyi ile çalışıldı. Katılımcıların Konfor Ölçeği puan ortalaması için yapılan Shapiro-Wilk normallik analizi sonucu söz konusu puanın normal dağılım göstermediği belirlendi. Konfor Ölçeği puan ortalaması için yapılmış olan gruplar aras1 karşılaştırma testlerinde parametrik olmayan test teknikleri kullanıldı. Çalışmada parametrik olmayan test tekniklerinden Mann Whitney U ve Kruskal Wallis testleri kullanıldı. Bağımsız iki grubun nicel bir değişken açısından karşılaştırılmasında, Mann Whitney $U$ testi, bağımsız ikiden fazla grubun $(k>2)$ nicel bir değişken açısından karşılaştırılmasında Kruskal Wallis testi kullanıldı. Katılımciların Konfor Ölçeği puanlarının demografik değişkenlere göre farklılık gösterme durumu Mann Whitney ve Kruskal Wallis testleri ile analiz edildi.

\section{Araştırmanın Etik Yönü}

Çalışmaya başlamadan önce İstanbul Medipol Üniversitesi Etik Kurulu'ndan etik onay (Karar No: 2015/661) ve kurum izni alındı. Çalışmaya katılan bireylere çalışma konusunda bilgi verilip yazılı onam alınd1. Perianestezi Konfor Ölçeği için yazardan mail yoluyla izin alınd.

\section{Bulgular}

Çalışmaya katılan bireylerin \%81' inin kadın, \%91,3'ünün evli, \% 33,9'nun lise mezunu, 
Tablo 1. Cerrahi Girişim Uygulanan Bireylerin Tanıtıcı Özelliklerine Göre Konfor Ölçeği’nden Aldıkları Sıra Ortalamalarının Karşılaştırılması ( N=218 )

\begin{tabular}{|c|c|c|c|c|c|}
\hline & Özellikler & $\mathrm{N}$ & Sira Ortalamas1 & Test değeri & P değeri \\
\hline \multirow{3}{*}{ Cinsiyet } & Kadın & & & \multirow{3}{*}{$\mathrm{U}=2569,500$} & \multirow{3}{*}{$\mathrm{p}=0,011$} \\
\hline & & 179 & 103,94 & & \\
\hline & Erkek & 39 & 132,12 & & \\
\hline \multirow[t]{5}{*}{ Yaş } & $19-29$ & 35 & 103,59 & \multirow{5}{*}{$\mathrm{KW}=4,540$} & \multirow{5}{*}{$\mathrm{p}=0,338$} \\
\hline & $30-40$ & 53 & 97,88 & & \\
\hline & $41-50$ & 57 & 111,00 & & \\
\hline & $51-60$ & 26 & 98,76 & & \\
\hline & $61-72$ & 47 & 121,84 & & \\
\hline \multirow{4}{*}{$\begin{array}{l}\text { Eğitim } \\
\text { Durumu }\end{array}$} & Okur-yazar & 10 & 98,25 & \multirow{4}{*}{$\mathrm{KW}=0,844$} & \multirow{4}{*}{$\mathrm{p}=0,839$} \\
\hline & İlköğretim & 68 & 107,17 & & \\
\hline & Lise & 74 & 106,41 & & \\
\hline & Üniversite & 66 & 113,73 & & \\
\hline \multirow{3}{*}{$\begin{array}{l}\text { Çalışma } \\
\text { durumu }\end{array}$} & Evet & & & \multirow{3}{*}{$\mathrm{U}=5041,500$} & \multirow{3}{*}{$\mathrm{p}=0,160$} \\
\hline & & 97 & 114,03 & & \\
\hline & Hayır & 121 & 102,09 & & \\
\hline \multirow{3}{*}{$\begin{array}{l}\text { Sosyal } \\
\text { Güvence }\end{array}$} & SGK & 196 & 102,84 & \multirow[b]{3}{*}{$\mathrm{KW}=1567,000$} & \multirow[b]{3}{*}{$\mathrm{p}=0,605$} \\
\hline & Ücretli & 18 & 110,44 & & \\
\hline & Özel Sağlık Sigortası & 4 & 98,72 & & \\
\hline \multirow[t]{3}{*}{$\overline{\text { Gelir Durumu }}$} & Gelir giderden az & 17 & 111,38 & \multirow{3}{*}{$\mathrm{KW}=0,062$} & \multirow{3}{*}{$\mathrm{p}=0,970$} \\
\hline & Gelir gidere denk & 175 & 107,57 & & \\
\hline & Gelir giderden fazla & 26 & 108,65 & & \\
\hline Kronik & Var & 52 & 119,58 & & \\
\hline Hastalık & Yok & 166 & 105,67 & $\mathrm{U}=3740,000$ & $\mathrm{p}=0,163$ \\
\hline \multirow{2}{*}{$\begin{array}{l}\text { İlaç } \\
\text { Kullanımı }\end{array}$} & Yok & 188 & 33,15 & \multirow[b]{2}{*}{$\mathrm{U}=430,500$} & \multirow[b]{2}{*}{$\mathrm{p}=0,485$} \\
\hline & Var & 30 & 29,95 & & \\
\hline \multirow{3}{*}{ Alışkanlıklar } & Alkol & 3 & 24,29 & & \multirow[b]{3}{*}{$\mathrm{p}=0,175$} \\
\hline & Sigara & 46 & 35,83 & & \\
\hline & Yok & 169 & 40,66 & $\mathrm{KW}=36,500$ & \\
\hline
\end{tabular}

KW: Kruskal Wallis Analizi, U: Mann Whitney-U testi

\%31,2'sının ilköğretim mezunu, \%30,3'ünün üniversite mezunu olduğu görüldü. Katılımcıların yaş grubuna göre dağılımları incelendiğinde, \%26,1'inin 41-50, \%24,3'ünün 30-40, \%21,6'ünün 61-72 yaş grubunda olduğu bulundu. Araştırmaya kat1lan bireylerin \%55,5'inin herhangi bir kurumda çalışmadığ $1, \% 89,9$ 'unun sosyal güvenlik kurumu olarak sağlık hizmeti aldıkları görüldü. Ekonomik durum değerlendirildiğinde, \%80,3 'ünün gelir düzeyinin gider düzeyine denk olduğu, \%23,9'unun en az bir kronik hastalığı olduğu ve bu hastalığı sebebiyle \%86,3 'ünün sürekli ilaç kullandığ 1 görüldü. Bireylerin \%21,1'unun sigara, $\% 1,3$ 'ünün alkol alışkanlığı olduğu görüldü.. 
Tablo 2. Cerrahi Girişim Uygulanan Bireylerin Hastalık ve Ameliyata ilişkin Özelliklerine Göre Konfor Ölçeği’nden Aldıkları Sıra Ortalamalarının Karşılaştırılması ( N=218 )

\begin{tabular}{|c|c|c|c|c|c|}
\hline & Özellikler & $\mathrm{N}$ & $\begin{array}{l}\text { Sira } \\
\text { ortalamalar1 }\end{array}$ & Test değeri & p değeri \\
\hline Geçirilmiş & Var & 131 & 109,30 & & \\
\hline Ameliyat & Yok & 87 & 89,76 & $\mathrm{U}=3817,000$ & 0,024 \\
\hline \multirow{3}{*}{$\begin{array}{l}\text { Önceki hastane } \\
\text { izlenimleri }\end{array}$} & İyi & 89 & 68,56 & \multirow{3}{*}{$\mathrm{KW}=0,084$} & \multirow{3}{*}{0,959} \\
\hline & Orta & 37 & 66,42 & & \\
\hline & Kötü & 9 & 68,94 & & \\
\hline \multirow{3}{*}{$\begin{array}{l}\text { Şimdiki } \\
\text { ameliyata } \\
\text { tutum }\end{array}$} & Olumlu & 188 & 108,17 & \multirow[t]{3}{*}{$\mathrm{KW}=3,614$} & \multirow[t]{3}{*}{0,164} \\
\hline & Olumsuz & 16 & 81,59 & & \\
\hline & Farketmez & 14 & 91,25 & & \\
\hline \multirow[t]{2}{*}{ Ameliyat Planı } & Acil & 67 & 100,63 & \multirow[t]{2}{*}{$\mathrm{U}=4323,500$} & \multirow[t]{2}{*}{0,294} \\
\hline & Planlı & 151 & 110,37 & & \\
\hline \multirow[t]{7}{*}{ Ameliyat türü } & Kolesistektomi & 17 & 144,97 & \multirow[t]{7}{*}{$\mathrm{KW}=13,483$} & \multirow[t]{7}{*}{0,036} \\
\hline & Apendektomi & 13 & 129,08 & & \\
\hline & Herni & 18 & 128,81 & & \\
\hline & Rinoplasti & 10 & 121,80 & & \\
\hline & Sezaryen & 128 & 97,75 & & \\
\hline & Diz Protezi & 15 & 118,67 & & \\
\hline & Lomber Disk Hernisi & 17 & 111,74 & & \\
\hline \multirow[t]{2}{*}{ Ameliyat şekli } & Laparoskopik & 21 & 130,50 & \multirow[t]{2}{*}{$\mathrm{U}=1627,500$} & \multirow[t]{2}{*}{0,108} \\
\hline & Açık ameliyat & 197 & 107,26 & & \\
\hline \multirow[t]{2}{*}{ Anestezi türü } & Genel & 187 & 108,23 & \multirow[t]{2}{*}{$\mathrm{U}=2596,500$} & \multirow[t]{2}{*}{0,479} \\
\hline & Spinal & 31 & 99,76 & & \\
\hline
\end{tabular}

Katılımcılardan \% 60,2 'sinin daha önce ameliyat geçirip yatış deneyimi olduğu, \%65,9'unun sağlık bakımı alma deneyimini "iyi" olarak değerlendirdikleri görüldü. Bireylerin \%86,2'sinın şimdiki ameliyatına karşı tutumunun "iyi", \% 7,3'ünün "kötü" olduğu görüldü. Ameliyat geçiren hastaların \%98,2'sinin ameliyat öncesi ve sonrası yanında refakatçisi olduğu belirlendi. Çalışmaya alınan bireylerin \%69,3'üne planlı, diğerlerine acil ameliyat uygulandığı belirlendi. Hastalara uygulanan ameliyatların tipi incelendiğinde sezaryen geçiren hastaların oranının $\% .58,7$ olduğu görüldü. Hastaların \%90,4'üne açık cerrahi girişim \%9,6'sına laparoskopik (kapalı) cerrahi girişim uygulandiğ 1 , uygulanan anestezi türüne göre yapılan değerlendirmede hastaların $\% 85,8$ 'inin genel anestezi ve \%14,2'sinin spinal anestezi 
Tablo 3. Cerrahi Girişim Uygulanan Bireylerin Ağrı Düzeylerine Göre Konfor Ölçeği'nden Aldıkları Sıra Ortalamalarının Karşılaştırılması ( $\mathrm{N}=218$ )

\begin{tabular}{|c|c|c|c|c|c|}
\hline & Özellikler & $\mathrm{N}$ & Sira Ort & Test değeri & P değeri \\
\hline \multirow[t]{3}{*}{ Ağr1 Şiddeti } & Hafif ağr1 & 63 & 118,74 & \multirow{3}{*}{$\mathrm{KW}=11,515$} & \multirow{3}{*}{$\mathrm{p}=0,003$} \\
\hline & Orta şiddette ağrı & 81 & 120,75 & & \\
\hline & Şiddetli ağrı & 74 & 89,32 & & \\
\hline \multirow[t]{2}{*}{ Ağr1 Yeri } & Kesi yeri ağrıs1 & 174 & 106,08 & \multirow[b]{2}{*}{$\mathrm{U}=3556,500$} & \multirow[b]{2}{*}{$\mathrm{p}=0,790$} \\
\hline & $\begin{array}{l}\text { Gaz, sırt, baş, genel vücut } \\
\text { ağris1 }\end{array}$ & 44 & 103,33 & & \\
\hline \multirow[t]{5}{*}{ Ağr1 Kesici } & Parasetamol & 48 & 67,43 & \multirow{5}{*}{$\mathrm{KW}=0,739$} & \multirow{5}{*}{$\mathrm{p}=0,864$} \\
\hline & Narkotik Analjezik & 37 & 56,79 & & \\
\hline & NSAIII & 63 & 68,46 & & \\
\hline & NSAIII ve Narkotik & 49 & 59,54 & & \\
\hline & Analjezik Almayan & 21 & 71,26 & & \\
\hline \multirow[t]{2}{*}{ Bulant1 } & Var & 38 & 109,37 & & \multirow[b]{2}{*}{$\mathrm{p}=0,989$} \\
\hline & Yok & 180 & 109,53 & $\mathrm{U}=3415,000$ & \\
\hline \multirow[t]{2}{*}{ Antiemetik } & Alan & 25 & 106,20 & \multirow[b]{2}{*}{$\mathrm{U}=2330,000$} & \multirow[b]{2}{*}{$\mathrm{p}=0,781$} \\
\hline & Almayan & 193 & 109,93 & & \\
\hline
\end{tabular}

yöntemi ile ameliyat olduğu belirlendi. Tablo 1'de cerrahi girişim uygulan bireylerin tanıtıcı özelliklerine göre konfor ölçeği puan ortalamaları verildi. Katılımcılardan kadın ve erkek gruplar arasinda istatistiksel olarak anlamlı farkl111k bulundu $(\mathrm{U}=2569,5 ; \mathrm{p}<0,05)$. Kadınların puan sıra ortalamalar1 103,94 iken erkeklerin puan ortalamaları 132,12'dir. Ameliyat geçiren erkeklerin konfor düzeyi kadınlara göre daha yüksek bulundu. Hastaların yaş grupları, medeni durum, eğitim durumu, çalışma durumu, sosyal güvence, gelir düzeyi, alışkanlıklarına göre konfor ölçeği puan ortalaması açısından istatistiksel olarak anlamlı farkl11ık bulunmad1 (U=36,500; p>0,05). Kronik hastalığı olan ve olmayanlar arasında konfor puan ortalaması açısından anlamlı farklılık bulunmadı $(\mathrm{U}=3740,000 ; \quad \mathrm{p}>0,05)$. Kronik hastalığ dolayısıyla ilaç kullanan ve kullanmayan grupların puan ortalamaları arasında anlamlı farklılık bulunmadi (U=430,500; $p>0,05)$.

Tablo 2'de cerrahi girişim uygulan bireylerin hastalık ve ameliyata ilişkin özelliklerine göre konfor ölçeği puan ortalamaları görülmektedir. Çalışmaya katılan hastalardan önceden ameliyat geçiren ile geçirmeyen grupların konfor puan ortalamas1 arasinda istatistiksel olarak anlamlı farklılık bulundu ( $U=3817,00 ; \mathrm{p}<0,05)$. Ameliyat geçirmiş olan hastaların konfor puan ortalamaları 109,30 iken ameliyat geçirmeyenlerin 89,76'dır. Planlı ameliyat geçiren hastaların konfor ölçeği puan ortalaması 110,37 iken acil ameliyat geçirenlerin ise 100,63 'dir. Planlı ameliyat geçirenlerin konfor puanı diğerlerinden daha yüksek olmasına karşın fark, istatistiksel olarak anlamlı bulunmadı ( $U=4323,500 ; p>0,05)$.

Cerrahi girişim uygulan hastalarda ameliyat tipine göre konfor puanı incelendiğinde gruplar arasinda anlamlı fark bulundu $\left(x^{2}=13,483 ; \mathrm{p}<0,05\right)$. Kolesistektomi ameliyat1 geçiren hastaların konfor puanı sıra ortalamaları 144,97; apendektomi ameliyat1 geçirenlerin 129,08; herni ameliyatı geçirenlerin 128,81 bulundu. Apendektomi yapılan hastaların konfor düzeyinin herni ameliyatı olanlara göre daha yüksek olduğu, kolesistektomi yapılanların konfor düzeyinin diğerlerinden yüksek olduğu belirlendi. Anestezi tipine göre konfor puanları incelendiğinde spinal anestezi alan hastaların konfor puan 
ortalaması genel anestezi alanlarınkinden yüksek bulundu ancak fark istatistiksel olarak anlaml bulunmadi $(U=2596,500 ; p>0,05)$.

Cerrahi girişim uygulan bireylerde ameliyattan 24 saat sonrasinda hafif, orta ve şiddetli ağrısı olan grupların konfor puanları arasında anlamlı fark bulundu $\left(x^{2}=11,515 ; \mathrm{p}<0,05\right)$. Orta şiddette ağrısı olanların konfor puanı ortalamaları 120,75 iken şiddetli ağrısı olanların konfor puan ortalamas1 89,32 'dir. Şiddetli ağrıs1 olanların konfor düzeyi hafif ve orta şiddette ağrısı olanlardan düşük bulundu. Kesi yeri ağrısı yaşayanların konfor puan ortalaması 106,08, diğer türde ağrıs1 olanların konfor puan ortalaması 103,33'dur, her iki grubun ortalamaları arasındaki fark istatistiksel olarak anlamlı bulunmadı $(\mathrm{U}=3556,500 ; \mathrm{p}>0,05)$. Farklı tipte ağr 1 kesici verilen gruplar arasında konfor puanı açısından anlamlı farkl111k bulunmad1 $\left(x^{2}=, 739 ; \mathrm{p}>0,05\right)$. Bulantı durumuna göre ve antiemetik ilaç kullanımına göre grupların konfor puanı arasında anlamlı fark bulunmadı ( $\mathrm{U}=3415,00 ; \mathrm{p}>0,05$ ve $\mathrm{z}=2330,00 ; \mathrm{p}>0,05$, Tablo 3 ).

\section{Tartışma}

Cerrahi girişimler, yaşamı doğrudan güvence altına almayı amaçlayan uygulamalar olmakla beraber hasta bireyi tüm boyutları ile etkileyen bir travma olduğundan konforun bozulmasina neden olabilmektedir (13). Sağlık bakımı veren merkezlerin fiziksel ve sosyal yönden sağladığı konfor, sağlık bakımı veren hemşirelere olan güveni ve hasta memnuniyetini arttırmaktadır (14). Konforun birçok yönü bulunduğundan, konforu geliştirmek üzere yapılan girişimlerin, konfor düzeyi üzerinde beklendiğinden çok daha büyük etkisi olabilmektedir ve perioperatif bakım sürecinde bu girişimler yer almaktadır (2).

Ameliyat geçiren bireylerin tanitıcı özelliklerine göre incelendiğinde çalışmamıza katılan bireylerin \% 81'inin kadın \%19'unun erkek olduğu ve erkek hastaların konfor düzeyinin kadınlara göre daha yüksek olduğu bulundu. Üstündağ' in koroner arter bypass greft cerrahisi uygulanan hastaların konfor düzeyi çalışmasında hastaların \%71.2'sinin erkek olduğu ve erkek hastaların konfor düzeylerinin daha yüksek olduğu belirtilmiştir (15). Çalışmamızda kadın hastaların konfor düzeyinin düşük bulunması kadınların ev ve çocuklarına yönelik sorumluluklarının fazla olması nedeniyle konfor düzeyinin etkileneceğini düşündürmüştür.

Araştırmamızda katılımcıların \%91,3'ünün evli olduğu, medeni durumun konfor puanını etkilemediği bulundu. Sönmez'in 'Koroner arter bypass greft ameliyatı uygulanan hastaların konfor ve kaygı deneyimlerinin değerlendirilmesi" adlı çalışmasının bulguları çalışma bulgularımızla paraleldir (16). Öte yandan Sayedfatemi ve ark.'nın çalışmasında tek başına yaşayan hastaların konfor düzeyinin evli olanlardan düşük olduğu, boşanmış kişiler ailenin sosyal desteğini kaybettiğinden cerrahi girişimin konforu olumsuz etkileyen sorunları tetiklediğini ifade etmişlerdir (17).

Araştırmamızda ameliyat geçiren hastaların \%33,9'nun lise mezunu olduğu ve eğitim durumlarına göre gruplar arası karşılaştırmada istatistiksel açıdan anlamlı bir farkın olmadığı görüldü. Günçayır'ın kalça protezi ameliyatı olacak hastalara verilen eğitimin ameliyat sonrası konfor düzeyi ve günlük yaşam aktivitelerine etkisi isimli çalışmasında da eğitim düzeyinin konforu etkilemediği bulunmuştur (18). Ancak Üstündağ'ın ve Sayedfatemi'nin çalışmalarında eğitim düzeyi yükseldikçe konfor düzeyinin arttığı belirtilmiştir $(15,17)$. Çalışmamızda gelir düzeyine yönelik gruplar arası karşılaştırmada istatistiksel açıdan anlamlı fark saptanmadı. Ekonomik yönden iyi durumda olmanın beraberinde kendine güveni, rahatlı̆̆ 1 getirdiği varsayılmaktadır. $\mathrm{Bu}$ varsayım Üstündağ'ın koroner arter bypass greft cerrahisi uygulanan hastaların konfor düzeyi bulgularında da desteklenmekte olup, gelir düzeyi düşük olan hastaların konfor düzeylerinin de düşük olduğu belirtilmiştir (15).

Ameliyat geçiren bireylerin hastalık ve ameliyata ilişkin özelliklerine göre dağılımı ele alındığında katılımcılardan \%60,2‘sinin daha önce ameliyat geçiren bireyler olduğu ve ameliyat deneyimi, hasta konforunu doğrudan etkilediği ve hasta konforunu arttırdığı bulundu. Sönmez'in koroner arter bypass greft ameliyatı uygulanan hastalarin konfor ve kayg1 deneyimlerinin değerlendirilmesi adlı çalışmasında ve Üstündağ'ın koroner arter bypass greft cerrahisi uygulanan hastaların konfor düzeyi çalışmasında daha önceki cerrahi deneyimlerin konfor düzeyi üzerinde istatistiksel açıdan anlamlı fark oluşturmadığ belirtilmiştir. Çalışmamızda daha önceki cerrahi deneyimlerin hastanın hastane ortamını 
benimsemesi, önceden cerrahi ve anestezi sürecine ait bilgisinin olması, hastanede yatış sürecinde konfor gereksinimlerini deneyimlemiş olması konfor düzeyini olumlu yönde etkileyeceğini düşündürmüştür.

Cerrahi girişim geçirdikten sonra hastaların \%65,9'unun önceki sağlık bakım deneyimini "iyi”" olarak değerlendirdikleri görüldü. Ameliyat geçiren bireylerin \%86,2'sinın şimdiki ameliyatına karşı tutumunun "iyi” olduğu görüldü. Çalışmamızda hastaların sağlık bakımı verenlerden memnun olması konfor düzeylerini olumlu yönde etkilediğini düşündürmektedir.

Çalışmamıza alınan bireylerin \%69,3'üne planlı ameliyat uygulandığı belirlendi. Planlı cerrahi girişim geçiren hastaların konfor ölçeği puan ortalamas1 110,37 iken acil cerrahi girişim geçiren hastaların 100,63 olduğu görüldü, fark istatistiksel olarak anlamlı bulunmadi. Acil cerrahi geçiren hastalarda konfor puanındaki farklılığın ameliyat öncesi fiziksel ve psikolojik hazırlık için yeterli zaman olmamasından kaynaklandığı, planlı cerrahi girişimlerde ameliyat öncesi hazırlıkta hemşireler tarafindan verilen hasta eğitimin konfor düzeyinin artmasına yönelik girişimler için yeterli zamanın olmasına bağlı olduğu düşünülebilir.

Ameliyat tiplerine göre konfor düzeyleri incelendiğinde ise kolesistektomi ameliyatı geçiren hastaların en yüksek konfor düzeyinde olduğu, sezaryen geçirenlerin ise en düşük konfora sahip oldukları bulundu. Pınar ve ark.'nın 2009 yılında yaptıkları annelerin doğum sonu konforunu etkileyen faktörler adlı araştırmada sezaryen ile doğum yapan annelerin konfor düzeylerinin normal doğum yapan annelerden düşük olduğu belirtilmiştir (19). Metinoğlu'nun çalışmasında (2016) da sezaryen ile doğum yapan annelerin konfor düzeyleri normal doğum yapanlara göre düşük olduğu belirtilmiştir (20). Kolesistektomi ameliyatları laparoskopik cerrahi tekniği ile uygulandığından dolayı bu hastalarda konfor düzeyinin yüksek olduğu düşünülmüştür. Sezaryen geçiren hastaların konfor düzeyinin düşük olması ameliyat sonrası yenidoğan bebeklerin bakım gereksinimlerine bağlı olabileceği düşündürmüştür.

Çalışmamıza alınan hastaların \%90,4' üne açık cerrahi girişim, diğerlerine ise laparoskopik cerrahi işlem uygulandığı belirlendi. Konfor puan ortalamalarına bakıldığında laparoskopik ameliyat olanların konfor puan ortalamaları 130,50 iken açık cerrahi girişim geçirenlerin konfor puan ortalaması
107,26 bulundu, konfor puan ortalamaları yönünden gruplar arasında anlamlı fark bulunmadı. Literatür bilgisine göre laparoskopik ameliyat geçirenlerde konfor düzeyinin açık ameliyata göre yüksek olması beklendiği halde böyle bir bulgu elde edilememiştir. $\mathrm{Bu}$ durumun laparoskopik ameliyat geçiren vaka sayısının azlığından kaynaklanabileceği düşünülmüştür.

Uygulanan anestezi türüne göre yapılan değerlendirmede hastaların \%85,8'inin genel anestezi ve \%14,2'sinin spinal anestezi yöntemi ile cerrahi girişim uygulandığ 1 saptandı. Çalışmamızda anestezi yönteminin hastanın konfor düzeyini etkilemediği istatistiksel açıdan anlamlı bir fark oluşturmadığ1 görüldü. Ünülü'nün perikardiyum 6 noktasina bilek band1 ile akupresürün ameliyat sonrası bulantı kusma ve konfor düzeyine etkisi çalışmasında da anestezi yöntemlerinin hastanın konfor düzeyi üzerine etkisi olmadığı bildirilmiştir. Çalışma bulgumuz Ünülü'nün çalışması ile benzerdir (21).

Ağrı değerlendirmesinde ölçek kullanımı hasta ile hastanın bakımını sürdüren hemşire ve hekimler arasında objektif değerlendirmeyi sağlamaktadır (22). Bu çalışmada numerik ağrı ölçeği ile hastaların ağrı durumları değerlendirildiğinde ameliyat geçiren bireylerde ağrı şiddeti farklı olan grupların konfor puanı arasinda anlamlı fark bulundu. Sönmez'in koroner bypass ameliyatı uygulanan hastaların konfor ve kaygı deneyimlerinin değerlendirilmesi çalışmasında ağrı düzeyi ile konfor karşılaştırıldığında aralarında istatistiksel açıdan anlamlı bir fark olduğu, hafif ağrı çeken hastaların konfor düzeyinin, orta ve şiddetli ağrıs1 olanlara göre daha yüksek olduğu belirtilmiştir. Bizim çalışmamızda orta düzeyde ağrısı olan hastaların hafif ağrı çeken hastalardan daha fazla konfora sahip olmaları hastanın ağrı düzeyi düştükçe diğer konfor gereksinimlerine yönelik beklentilerini arttırdıklarını düşün-dürmüştür.

Ağrı yerine göre yapılan karşılaştırmada istatistiksel açıdan anlamlı bir fark olmadığ görüldü. Ameliyat sonrası hastaların \%79.8'inin insizyon yerine bağlı ağrı yaşadığ $\% 20,2$ 'sinin baş ağrıs1, gaz sancıs1 veya sırt ağrısı yaşadığı görüldü. Ağr1 kesici ilaçlarla konfor arasında anlamlı bir ilişki olmadığı görüldü. Ağrı gidermek amacı ile hastaların \%28,8'ine NSAI verildiği ve ilaç grupları ile konfor arasında istatistiksel açıdan anlamlı bir farkın olmadığı görüldü. Nonfarmakolojik yöntemlerin farmakolojik yöntemler ile 
kullanılmasının da hasta konforunu etkileyeceği düşünülebilir.

Ameliyat sonrası hastayı rahatsı eden ve en sik rastlanan sorunlardan biri bulantı ve kusmadır. Çalışmaya alınan bireylerin ameliyat sonrası bulantı durumları incelendiğinde \%17,4'ünün ameliyat sonrası bulantı yaşadığı görüldü. Postoperatif dönemde görülen bulantı ve kusma nedenleri arasında; hastanın bulantı kusmaya yatkınlığı, anestezi ilaçları ile cerrahi bölgenin ve tipinin özelliği, hareket kısıtlılığ1, postoperatif ağr1 yoğunluğu ve postoperatif ilaç uygulaması yer almaktadır Hastaların ameliyat sonrası dönemde bulantı hissetmesinin de konforu azaltıcı bir etken olabileceği belirlenmiştir.

\section{Sonuç ve öneriler}

$\mathrm{Bu}$ çalışmada ameliyat geçiren bireylerin konfor puan ortalamaları 4,82 $\pm 0,61$ bulunmuştur. Bu puan ortalamaya yakın ve üzerinde bir puan olarak değerlendirilmektedir. Araştırmada erkek hastaların konfor düzeyinin kadınlarınkinden yüksek olduğu, daha önce ameliyat geçirmiş olmanın konfor düzeyini arttırdığ 1 , kolesistektomi ameliyatı geçiren hastaların konfor düzeyinin diğer ameliyatları geçiren hastalardan daha yüksek olduğu, şiddetli ağrının konfor düzeyini düşürdüğü belirlenmiştir. Elde edilen bu sonuçlara dayanarak ameliyat geçiren hastalarda bütüncül yaklaşımla konfor girişimlerinin planlaması, ameliyat sonrası ağr1 hasta konforunu olumsuz etkilediğinden ağrının giderilmesi için etkin bakım girişimlerinin yapılması önerilebilir. Bireyin konforunu arttırmak amacıyla benzer çalışmaların özgün ölçme araçları ile daha geniş örneklem gruplarında farklı zaman dilimlerinde yapılması önerilebilir.

\section{Araştırmanın Sınırlılıkları}

Araştırma İstanbul ilinde bulunan bir özel hastaneye başvuran hastalar üzerinde uygulandığ 1 için bulgularımız tüm ameliyat geçiren hastalara genellenemez.

\section{Kaynaklar}

1.Williams AM, Irurita VF. Emotional comfort: the patient's perspective of a therapeutic context. Int J Nurs Stud 2006; 43: 405-415.

2.Kolcaba K, Wilson L. Comfort care: a framework for perianesthesia Nursing. J Perianesth Nurs 2002; 17:104-114.
3.Kolcaba K, Kolcaba R. An Analysis of the Concept of Comfort. J Adv Nurs 1991;16:13011310.

4.Malinowoski A, Stamler LL. Comfort Exploration of The Concept İn Nursing. Journal of Advanced Nursing 2002; 39 (6), 599-606.

5.Kolcaba K, Wykle M. Comfort Research: Spreading Comfort Around The World. Reflections 1997; 23:12-13.

6.Kuğuoğlu S, Karabacak Ü. Genel Konfor Ölçeğinin Türkçe 'ye uyarlanması. İstanbul Üniversitesi Florence Nightingale Hemşirelik Yüksekokulu Dergisi 2008; 61 (16), 16-23.

7. Kolcaba K. Evolution of The Mid Range Theory of Comfort for Outcomes Research. Nurs Outlook 2001;49:86-92.

8. Kolcaba KY. Taxonomic Structure for the ConCept Comfort. Image J Nurs Sch 1991;23(4):237.

9. Shumaker RP. Perioperative Nursing. In: Black JM, Matassarin-Jacobs E, Eds. MedicalSurgical Nursing. 5th Ed. Philadelphia: WB Sounders; P.449-96. 1997.

10. Uğurlu SB. Postoperative neuropsychiatric system. Turkiye Klinikleri J Surg Med Sci 2007; 3 (27):23-8.

11. Krenzisckek D, Wilson L, Newhouse R, Mamaril M, Kane HL. Clinical evaluation of the aspan pain and comfort clinical guideline. $\mathbf{J}$ Perianesth Nurs 2004;19(3):150-9.

12. Mace L. An audit of post-operative nausea and vomiting, following cardiac surgery: scope of the problem. Nurs Crit Care 2003; 8:187-96.

13. Üstündağ H, Aslan FE. Perianestezi Konfor Ölçeğinin Türkçeye uyarlaması. Turkiye Klinikleri J Nurs Sci 2010; 2(2):94-9.

14. Gray LY, Sedhom L. Client satisfaction: traditional care versus cluster care. J Prof Nurs 1997; 13: 56-61.

15. Üstündağ H. Koroner Arter Bypass Greft Cerrahisi Uygulanan Hastaların Konfor Düzeyi, Doktora Tezi, Marmara Üniversitesi Sağlık Bilimleri Enstitüsü, İstanbul, 2009.

16. Sönmez A. Koroner Arter Bypass Greft Ameliyatı Uygulanan Hastaların Konfor ve Kayg1 Deneyimlerinin Değerlendirilmesi, Yüksek lisans Tezi, Trakya Üniversitesi Sağlık Bilimleri Enstitüsü, Tekirdağ, 2013.

17. Seyedfatemi N, Rafii F, Rezaei M, Kolcaba KJ. Comfort and Hope in the Preanesthesia Stage in 
Patients Undergoing Surgery Perianesthesia Nurs. 2014; 213-220.

18. Günçayır D. Kalça Protezi Ameliyatı Olacak Hastalara Verilen Eğitimin Ameliyat Sonrası Konfor Düzeyi ve Günlük Yaşam Aktivitelerine Etkisi, Yüksek lisans Tezi, Atatürk Üniversitesi Sağlı Bilimleri Enstitüsü Erzurum, 2011.

19. Pınar, G, Doğan, N, Algier, L, Kaya, N, Çakmak, F. Annelerin doğum sonu konforunu etkileyen faktörler. Dicle Tip Dergisi 2009; 184-190 .

20.Metinoğlu, M. Normal ve Sezaryen Doğum Yapan Kadınların Doğum Konfor Düzeyine Göre Karşılaştırması. Gebelik Doğum ve Lohusalık Kongresi. Ankara, 2016.

21.Ünülü M. Perikardiyum 6 Noktasına Bilek Bandı İle Akupresürün Ameliyat Sonrası Bulantı Kusma ve Konfor Düzeyine Etkisi, Yayınlanmamış Yüksek lisans Tezi, İstanbul Üniversitesi Sağlık Bilimleri Enstitüsü, İstanbul 2014.

22. Karadakovan A, Aslan Eti F. Dahili ve Cerrahi Hastalıklarda Bakım, Ağrı. 127-149. Ankara: Akademisyen. 2014. 